
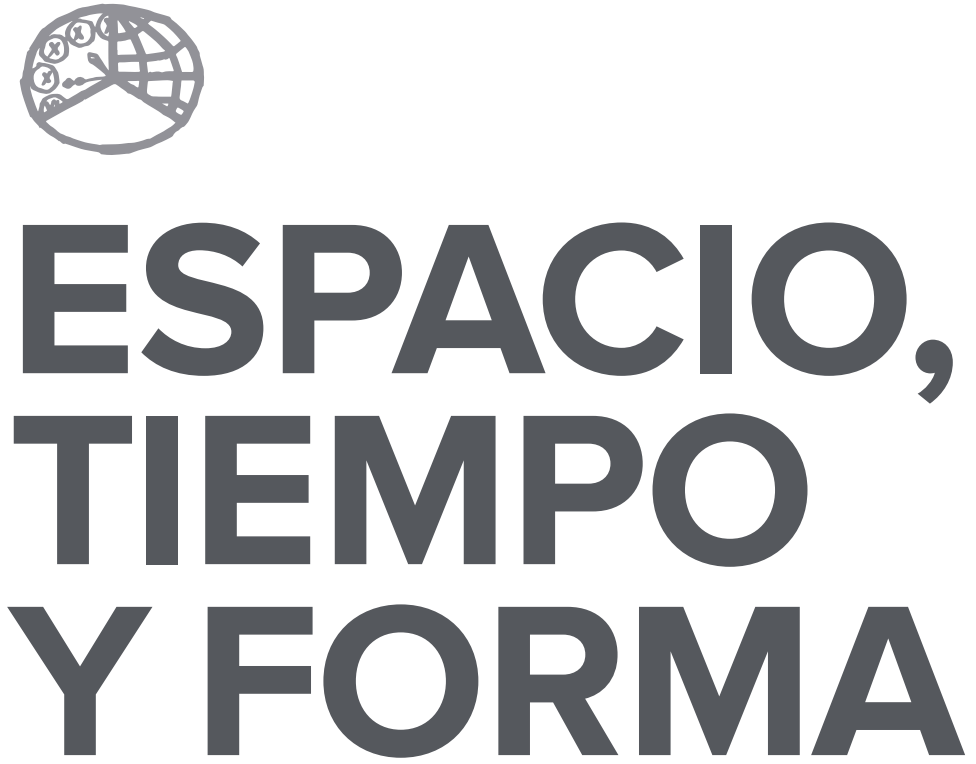

AÑO 2018

ISSN 0214-9745

E-ISSN 2340-1362

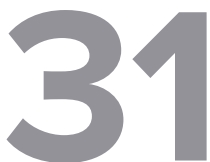

SERIE III HISTORIA MEDIEVAL

REVISTA DE LA FACULTAD DE GEOGRAFÍA E HISTORIA 



\section{ARTÍCULOS · ARTICLES}





\title{
LA PERVIVENCIA DEL FUERO DE CUENCA EN LOS INICIOS DE LA MODERNIDAD: EL TESTIMONIO DE LOS FUEROS DE CONSUEGRA Y REQUENA
}

\section{THE CONTINUED EXISTENCE OF THE CUENCA FUERO AT THE ONSET OF THE MODERN AGE: THE TESTIMONY OF THE CONSUEGRA AND REQUENA FUEROS}

\author{
Pedro Andrés Porras Arboledas ${ }^{1}$ \\ Recepción: 2017/7/11 · Comunicación de observaciones de evaluadores: 2017/9/7 · \\ Aceptación: 2017/9/11 \\ DOI: http://dx.doi.org/10.5944/etfiii.31.2018.21318
}

\section{Resumen}

Entrado el siglo XIII los fueros extensos castellanos resultan vaciados de contenido por los avances de la legislación real aplicada a todo el Reino, sin embargo, existen distintos ámbitos en los que se encuentran pervivencias, al menos, durante el siglo XVI. En este estudio se pasa revista a algunas de estas pervivencias a partir de dos ejecutorias de la Real Chancillería de Granada, relativas a los Fueros de Consuegra y Requena.

\section{Palabras clave}

Fueros de Cuenca; Consuegra y Requena; pervivencias de contenidos; derecho municipal; Real Chancillería de Granada.

\section{Abstract}

Throughout the thirteenth century the extensive Castilian fueros were emptied of content due to the advance of royal legislation applied to the whole kingdom. However, there are different areas in which we find a continued existence, at

1. Catedrático de Historia del Derecho, Instituto de Metodología e Historia de la Ciencia Jurídica, Universidad Complutense de Madrid. C. e.: pporras@der.ucm.es; ORCID ID: http://orcid.org/0000-0002-2884-8519. Researcher ID: K-9749-2017. 
least during the sixteenth century. This study considers some of these elements that have managed to survive from two judicial rulings of the Real Chancillería of Granada, relative to the Consuegra and Requena fueros.

\section{Keywords}

Fueros of Cuenca; Consuegra and Requena; Continuities; Municipal Law; Real Chancillería of Granada.

\section{INTRODUCCIÓN}

Es cuestión bien conocida cómo durante la Baja Edad Media los fueros extensos castellanos fueron perdiendo progresivamente vigencia, en la medida en que la legislación real, concebida para ser aplicada en todo el Reino, iba desplazando muchas de sus normas, de modo que desde la época de Alfonso X amplios sectores del contenido de los fueros, como las materias penal o procesal, fueron dejadas como antiguallas dentro de los vetustos fueros.

El empuje del derecho común acabaría por convertir estos textos en meros recuerdos de glorias pasadas, si bien los concejos y habitantes de esos lugares aforados siempre mantuvieron su aprecio por su fuero, que llevaron a confirmar reinado tras reinado, como el privilegio de que se trataba. A mi modo de ver, tan sólo pretendían tener una garantía de que los derechos contenidos en el fuero, con vistas a la propiedad de la tierra de su alfoz, serían respetados. Sin embargo, no sólo se trataba de eso, ya que había una serie de cuestiones que, aunque de carácter menor, seguían siendo invocadas por los ciudadanos a partir de los contenidos del fuero. Así, por ejemplo, en el caso de la ciudad de Úbeda, en la segunda mitad del siglo XV, se observaba tanto una disposición de carácter civil -el comprador de un caballo defectuoso no podía devolverlo hasta no pasar nueve días de su adquisición, según el título 58-A de su fuero- como otra penal -la caloña de 50 mrs. dispuesta en el título 30 del fuero para los que cortasen la nariz a otra persona, pena de carácter accesorio-. ${ }^{2}$

Esto es sólo una muestra, pero sin duda debieron de existir muchas más cuestiones que sobrevivieron al derecho común en los fueros, en aspectos que no atañían más que a cuestiones menores o puntuales. Buen ejemplo de eso,

2. Véase Pedro Andrés Porras Arboledas, «Un protocolo ubetense de 1459 y otros documentos procesales de los siglos XV y XVI». Cuadernos de Historia del Derecho, 2006, vol. XIII, p. 314, nota 1.

El Fuero de Úbeda fue editado en 1979, en Valencia, por los profesores M. PeSET, J. Gutiérrez CuAdrado y J. TRENCHS ODENA. 
además de los documentos que vamos a aportar en el siguiente punto, es el caso del derecho de troncalidad, de cuya observancia en tierras pobladas a fuero de Cuenca contamos con numerosos testimonios durante el siglo XVI, tema del cual daré cumplida cuenta en un próximo estudio. No obstante, hay que considerar el hecho de que tal vez ese derecho fuera reavivado a comienzos de esa centuria por lo dispuesto en las Leyes de Toro; ${ }^{3}$ en ese caso, habría que determinar si ese derecho había sobrevivido hasta 1505 o si, por el contrario, cobraría nueva vida de mano de la legislación regia. ${ }^{4}$

\section{DOS EJECUTORIAS DE LA REAL CHANCILLERÍA DE GRANADA}

Hoy de sobra son conocidas las ejecutorias reales de la Chancillería de Valladolid, pues existe una sección de su archivo (Reales Ejecutorias) que ha sido colgada en buena medida en red; no de menor importancia es la documentación contenida en el Registro General del Sello de la Chancillería de Granada, con la ventaja, en este caso, de que, junto a las reales ejecutorias, se conserva el resto de los documentos ordinarios o de trámite -citatorias, compulsorias, receptorias, requisitorias, incitativas, comisiones, etc.-, que precedían a la ejecutoria u operaban en la ejecución de la misma. ${ }^{5}$

De todas esas provisiones la más decisiva era la carta ejecutoria, en la que se recogía un resumen del proceso y se ordenaba a las justicias del Reino que ejecutasen la sentencia final inserta en la misma; se incluían todos los aspectos sobresalientes -demandas, contestaciones, réplicas y sentencias sucesivas, todo

3. Dispone la ley VI que los causantes sin descendencia legítima han de ser heredados por sus ascendientes, salvo del tercio del caudal, del que podían disponer libremente, todo ello salvo en las ciudades, villas y lugares do según el fuero de la tierra se acostumbran tornar sus bienes al tronco o la rayz a la rayz, tal como ocurría con el Fuero de Cuenca (Compendio de los comentarios extendidos por el maestro Antonio Gómez a las ochenta y tres Leyes de Toro ..., Madrid, 1785, p. 40).

4. En ocasiones, la existencia de una norma en el fuero que disponía el incómodo pago de unos derechos por parte de las aldeas a su metrópoli pudo provocar que el texto del fuero extenso acabase desapareciendo prematuramente, como considero que ocurrió en Mérida («Sobre el Fuero extenso de Mérida». Cuadernos de Historia del Derecho, 2012, vol. XIX, pp. 27-48), en otras, el concejo metropolitano intentó contener las pretensiones de una de sus aldeas por emanciparse, invocando torticeramente una de las leyes de su fuero extenso, lo que sucedió en Segura de la Sierra («Sobre el Fuero extenso de Segura de la Sierra (El poblamiento de la villa de Santiago de la Espada)». Revista de la CECEL, 2014, vol, XIV, pp. 7-22). Ambos ejemplos pertenecen al siglo XVI; ambos fueros se han perdido, pero gracias a esos litigios he podido demostrar su existencia, al menos.

5. No existe una sección dedicada a dicho registro, sino que los legajos que lo contienen van reseñados con numeración correlativa a partir del expediente 5.501, correspondiente a 1495. No existe previsión de digitalizar ni describir esas provisiones una por una, por lo que el estudioso ha de recorrer el penoso camino de mirar todas las cajas del período de su interés, una a una, teniendo en cuenta que cada caja contiene una media de 400 provisiones. Las ejecutorias se encuentran incluidas dentro del resto de las provisiones de trámite.

Aunque muchos investigadores creen que el único Registro General del Sello existente es el del Consejo Real, conservado en el Archivo General de Simancas, lo cierto es que cada Consejo y cada Chancillería tenían su propio registro, donde se atesoraban todas las provisiones emanadas de cada una de esas instituciones, no así las cédulas, que solían recogerse en libros cedularios. 
ello precedido del fallo de primera instancia, en caso de venir en apelación-, pero no las probanzas.

Gracias a dos de esas ejecutorias de la Chancillería granadina podemos aportar algunos datos sobre el tema que nos ocupa. En las siguientes páginas voy a presentar un resumen de ambos textos, dejando para el final el comentario de sus contenidos.

\subsection{PROCESOS DEL CONCEJO DE CONSUEGRA CONTRA EL PRIOR DE LA ORDEN DE SAN JUAN EN CASTILLA Y SU ALCALDE MAYOR EN SU PRIORATO Y LAS ALDEAS DE MADRIDEJOS, VILLAFRANCA Y VILLACAÑAS, COMO TERCEROS OPOSITORES (1508-1509 Y 1535-1538)}

En un momento indeterminado de los inicios del reinado de la Reina Juana el concejo de la villa sanjuanista de Consuegra, cabeza de su bailía, acudió al Consejo Real a quejarse de los agravios que les propinaban el prior, su alcalde mayor y demás subalternos; ${ }^{7}$ el Consejo consideró que el órgano competente era la Chancillería granadina y allí remitió la causa. Así, los consaburenses presentaron en Granada una batería de tres peticiones contra el prior don Álvaro de Zúñiga, que configuraba una demanda del siguiente tenor:

[A] «por la qual dixeron que el dicho don Álvaro d’Estúñiga, prior de la dicha Horden de San Juan, e sus alcaldes mayores, alguaziles e otros oficiales avían fecho e fazían a dicha villa de Consuegra e a sus lugares e aldeas muchos agravios e sinrazones contra razón e justicia e contra leyes de mys Reynos en perturbación e quebrantamiento de el Fuero a que es poblada la dicha villa e su tierra, en perjuyzio de sus usos e costunbres, e qu'especialmente heran agraviados en lo siguiente:

[1] Lo primero que, según el dicho Fuero, uso e costunbre de la dicha villa, que en cada un año se elegían oficiales, alcaldes, alguaziles, regidores por el domyngo primero después de la fiesta de San Myguel, los quales avían de ser ricos [y] abonados y que avían de tener cada uno dellos casa y heredades en la dicha villa e que avían de ser ábiles e suficientes, según manda la dicha ley del Fuero, e que avían de ser elegidos por los oficiales que fueron el año pasado confirmados por el dicho prior.

Lo qual avía quebrantado el dicho prior eligendo oficiales criados suyos, quales él quería e tenía por bien, sin tener las dichas calidades de la dicha ley, arrendando el alguazilazgo de la dicha villa a quien dava más precio por él e dándole la vara d'él, aviendo más respeto a su provecho que a proveer la dicha villa de alguazil suficiente, no dexando de elegir a la dicha villa oficiales del año pasado, según el dicho Fuero.

6. Archivo de la Real Chancillería de Granada, expte. 5.681. Ejecutoria de 1539, duplicada por extravío de la original en octubre de 1543, conteniendo proceso anterior de 1508-1509, en 26 hojas.

7. Los abusos de priores y comendadores sanjuanistas sobre sus vasallos manchegos eran proverbiales, como se recoge abundantemente en documentación de Alcázar de San Juan (PORRAS ARBOLEDAS, Pedro Andrés et alii. Documentos medievales del Archivo Municipal de Alcázar de San Juan (siglos XII-XV), Alcázar de San Juan, 2012, passim). Tal vez por ello estos vasallos protagonizaron una importante emigración a las cercanas tierras santiaguistas durante la administración del Emperador Carlos, por entender que el monarca preservaría mejor sus derechos. 
[2] E que, teniendo como tenía la dicha villa jurisdición alta e baxa e mero mysto ynperio para los pleytos y causas ceviles e crimynales de la dicha villa e su tierra, que el dicho prior e sus alcaldes mayores advocan a sí los pleytos pendientes ante los alcaldes, jueces de la dicha villa, no lo pudiendo ny deviendo fazer de derecho fazer la dicha advocación, deviendo en la dicha villa de termynar los dichos pleytos hasta sentencia definytiva por los juezes ante quyen se començaron.

[3] Otrosí, que, tenyendo solamente el dicho prior e sus alcaldes mayores jurisdición en la dicha villa e su tierra en grado de apelación, e no en otra manera, el dicho prior e sus alcaldes mayores conocían de primera ystancia en los pleytos de la dicha villa e su tierra, e que lo peor hera qu'estando el dicho prior e sus justicias absentes de la dicha tierra, citavan e llamavan de primera ystancia a vezinos de la dicha villa, sacándolos de su fuero e domicilio, no lo pudiendo ny deviendo fazer de derecho.

[4] E que ansí mysmo, que quando los dichos alcaldes mayores conocen en la dicha villa [y] su tierra de algún pleyto cebil e crimynal, que quando se yban de la dicha villa se llebavan tras sí los dichos pleytos e pleyteantes, e que sacavan los presos qu'estaban presos y los llebavan donde querían e tenían por bien, lo qual hera en grande agravyo e fatiga de los vezinos de la dicha villa de Consuegra.

[5] E otrosí, que el dicho prior e sus alcaldes mayores no guardan la ley del Fuero cerca de las penas e caloñas de los delinquentes, porque aquéllas pertenecían a los muros de la dicha villa e a otras partes donde la dicha ley lo aplicava y que, si alguna parte pertenecía al dicho prior, que hera la quarta parte de las penas de ciertos delitos nonbrados en la dicha ley e no más.

Contra lo qual el dicho prior proveyó de promutor fiscal e que llevava las dichas penas enteramente e que las justicias de dicho prior aplicavan las dichas penas a su cámara e al dicho promutor fiscal en su nombre.

[6] Otrosí, que el dicho prior nuevamente avía puesto alguaziles executores para andar por la dicha villa de Consuegra e su tierra a executar en personas singulares por deudas y otras cosas por mandamiento de los tenientes y alcaldes mayores del dicho prior, no pudiéndose fazer de derecho, porque las dichas execuciones se avían de cometer a los alguaziles y alcaldes de la dicha villa de Consuegra.

E que los vezinos de la dicha villa e su tierra recevían agravyos e estorsiones de los dichos esecutores, los quales se dexavan cohechar e pagavan lo que no devían por no yr a se quexar a los dichos tenientes qu'estavan apartados de los dichos lugares.

[7] Ytem, que los dichos tenientes e justicias e sus escrivanos no guardavan a la dicha villa e su tierra cerca de los derechos las leyes e hordenamientos de mys Reynos, llevando los derechos muy demasiados.

Porque me pedían y suplicavan sobre lo susodicho les mandase hazer conplimiento de justicia de el dicho prior e de sus juezes, mandándoles que guardasen a la dicha villa el dicho Fuero e las cosas contenidas en los dichos capítulos.

[B] Y que, de más de lo susodicho, Yo sabría que otros muchos agravios e sinrazones e nuebas ynposiciones recivían e avían recevydo del dicho prior e de sus alcaldes mayores, yéndoles y pasándoles contra el tenor y forma de el dicho Fuero y hordenamiento real que la dicha villa tenía del Rey don Alfonso, de gloriosa memoria, my progenytor, los quales dichos agravios serían espresados ante my, de lo qual todo pedían que les fuese fecho conplimiento de justicia.

[C] E ansí mesmo, por otra petición que ante los dichos my presydente e oydores por parte de la dicha villa fue presentada, dixo que, aliende de los agravyos susodichos, recivían del dicho prior otros muchos agravyos, especialmente los siguientes: 
[1] Lo uno qu'el dicho prior apremiava a los vezinos de la dicha villa e su tierra contra su voluntad a servir con bestias e carretas e gelas mandavan llevar cargadas donde querían e tenían por bien, e que, allende de los llevar apremiados, no les pagavan lo que merecían.

[2] Lo otro porque, siendo los térmynos y montes de la dicha villa e tierra e todo lo qu'estava dentro de su terretorio e que todo lo qu'estaba dentro de los dichos términos, el dicho prior de fecho les devyeda e defiende que no cacen en los dichos térmynos, e que avía puesto e ponía guardas para que los dichos sus partes no se aprovechasen de la caça de los dichos térmynos, e que los dichos sus partes, como señores de los dichos térmynos, defendían e acotavan la caça por algún tienpo e térmyno, que el dicho prior lo quebrantava e dava licencia a quyen quería e tenía por bien para que caçasen en los dichos térmynos en tienpo vedado por los dichos sus partes.

[3] Lo otro, porque a sus partes pertenecían las cosas mostrencas de la dicha villa e su tierra, aquello de quyen no se allava dueño, haziendo las diligencias que, según leyes destos mys Reynos, se deven fazer, e que el dicho prior tomava e ocupava las tales cosas halladas en perjuyzio de los dichos sus partes e su derecho.

[4] Lo otro, porque, siendo los dichos sus partes libres e teniendo libertad e facultad para yr a moler su pan a donde quyeren e tienen [por] bien, el dicho prior de poco tienpo a esta parte les apremiava que vaian a moler a un molino suyo, e que no les es tan provechoso ny tan cerca como los otros donde sus partes querían yr a moler.

Por ende, que me pedían y suplicavan que cerca de los susodichos capítulos hiziese a los dichos sus partes de el dicho prior conplimiento de justicia, pronunciando y declarando [que] las cosas sobredichas heran ynpuestas por el dicho prior e que no les pertenecen los derechos e preminencias que pretende, e que sus partes heran libres de todo ello e que pertenecían a los dichos sus partes, que les devían aver condegnado al dicho prior a que no molestasen ny ynquietasen a los dichos sus partes sobre lo susodicho e que gelo dexasen todo libre e desenbargado, ponyéndole perpetuo silencio sobre todo lo susodicho, mandando al dicho prior que diese caución sobre todo ello, e que de aquí adelante no pida ny demande sobre lo susodicho a los dichos sus partes, condegnándole más en todo lo que a llevado ynjustamente e llevará fasta que realmente e con efeto lo dexe todo e se desista dello, e en los daños e menoscavos que a los dichos sus partes sobre lo susodicho se le an recrecido y recrecieren.

E que esto pedía ante mí e ante los dichos my presidente e oydores por la remysión que les estava fecha de los del my Consejo, e porque el dicho prior hera presona poderosa e que tenía las justicias de su mano, tal que d'él no se podría alcançar conplimiento de justicia, salvo ante my, podía ser abydo por caso de corte notorio, e le mandase dar mi carta de enplazamiento. E fizo juramento en forma devida de derecho, aliende del dicho Fuero a que sus partes estavan poblados, que tenían testigos e escrituras, con que provar su yntención, según que más largamente en la dicha demanda se contenía».

\section{Presentada la demanda, la Chancillería tuvo la causa por caso de Corte y libró citatoria para el prior, el cual presentó un escrito en el que negaba todo lo expuesto en la demanda, afirmando:}

Que la jurisdicción de Consuegra pertenecía al prior y a la Orden, pudiendo nombrar oficiales municipales, «porque las partes contrarias dezían e el dicho su Fuero que no avía sido usado ny guardado, e que antes se avía usado e guardado lo contrario, e lo que dezía y alegava de ynmemorial tienpo a esta parte».

Que no avocaban las causas, aunque tenían derecho a hacerlo, pero que si lo hicieran lo impediría.

Que estando dentro del término de la bailía de Consuegra él podía conocer en primera instancia. 
Que podían llevar penas y calumnias por leyes, por costumbre y por privilegio del Rey y de sus antepasados «y que la ley del Fuero no disponía lo que dezían ni avía sydo usada ny guardada».

Que tenía costumbre de nombrar alguaciles ejecutores.

Que los tenientes, justicias y escribanos podían llevar sus derechos conforme a las costumbres de la villa y al arancel de la Orden, que si se habían cometido un exceso que lo mostrasen y lo castigaría.

Que cuando tenían que traer los diezmos de una villa a otra tenían conveniencia antigua para pagárselo, «especialmente que, aunque algunos derechos pagan las partes contrarias en maravedíes, que heran e son obligados a los pagar de la moneda de entonces e que de su valor e bondad de ello que agora no lo pagavan así, y pues que el dicho prior no les crecía los maravedíes entonces si no mucho menos e que por esto no hera razón que las partes contrarias que quexasen dello, quanto más que abían de estar por la costunbre que se abía tenido e usado tan luengamente».

Que los términos eran de la Orden y el prior podía vedar la caza cuando quisiera, «según e como se hazía en estos mis Reynos por todos los grandes dellos para su recreación e servicio mío», que solo vedaba la caza en los lugares en donde había costumbre.

Que el prior y el alcaide de la fortaleza de Consuegra tenían privilegio para vedar la caza o dar licencia para cazar.

Que los mostrencos por leyes, privilegio y costumbre pertenecían a la Orden.

Y que por privilegio costumbre y posesión inmemorial sus vasallos eran obligados a ir a moler a los molinos del prior.

Pide absolución. ${ }^{8}$

Tras la conclusión dictaron los oidores sentencia de vista, por la que fallaron que el concejo de Consuegra había probado su intención, no así el prior respecto a las excepciones presentadas:

«Por ende, [1] que devemos de mandar e mandamos que la dicha villa de Consuegra pueda nonbrar e nonbre alcaldes, alguazil e regidores, un domyngo después de San Myguel de cada un año, conforme a la ley de su Fuero, el qual nombramiento mandamos que hagan de la manera siguiente: que nonbren para alcaldes quatro buenas presonas, vezinos de la dicha villa de Consuegra, e para alguazil otras dos personas e otras dos buenas presonas para cada regidor que hoviese de aber en la dicha villa, e con el dicho nonbramiento mandamos que bayan al dicho prior de San Juan, el qual mandamos que pueda elegir e nonbrar de los susodichos e no de otros algunos por oficiales las presonas que para los dichos oficios le pareciere que son más ábiles e suficientes.

[2] E otrosí, que devemos de mandar e mandamos que el que ansí fuere nonbrado e elegido por alguazil de la dicha villa cunpla e execute lo que por los alcaldes de la dicha de Consuegra lo que fuere mandado por los dichos alcaldes de la dicha villa e tierra.

[3] E reservamos en Nos para declarar e determinar adelante si el dicho prior de San Juan puede poner alguazil para executar sus mandamientos e de su alcalde mayor.

[4] E otrosí, que devemos mandar e mandamos que los alcaldes hordinaryos de la dicha villa puedan conocer y conozcan en primera ystancia e todas e qualesquier causas cebiles e cremynales e qualesquier presonas, e qualesquier que fagan en la dicha villa e su terretorio, e que después

8. El concejo concluye, siendo dictada sentencia de recibimiento a prueba; en ese estado el concejo pidió restitución, que le fue concedida; se hicieron probanzas y fueron publicadas. El concejo presenta escrito de bien probado. Notificada la parte contraria, no alega nada, por lo que el tribunal concluye para sentencia definitiva. 
de començados los dichos negocios ante los dichos alcaldes o qualquier dellos, el alcalde mayor puesto por el dicho prior no los pueda ynivir ny advocar a sí a los dichos pleytos, salvo por vía de apelación.

[5] E ansí mysmo mandamos que el dicho alcalde mayor pueda conocer y conozca de primera ystancia en la dicha villa en los negocios cebiles e crimynales que ant'él vinyeran de manera que ante quien se començare el pleyto de primera ystancia allí se fenezca e acave fasta que d'él apele, si lugar hoviere apelación. E que esto se entienda residiendo el dicho alcalde mayor en la dicha villa de Consuegra, pero que, si se fuere o absentare de la dicha villa a otra parte, que remita los tales pleytos a los alcaldes hordinaryos de la dicha villa, para que los vean y fenezcan y acaben, por manera que el dicho alcalde mayor no pueda sacar ni saque los tales pleytos ny pleyteantes fuera de la dicha villa.

[6] Otrosí, que devemos mandar e mandamos que el dicho prior ny sus alcaldes mayores no puedan llebar y lleben de las penas e calonias de los delitos que se cometieren en la dicha villa o tierra más de una quarta parte, que son de el homezillio e de la muger forçada e de la fuerça de la casa de el señor, e que del hurto lleve el dicho prior la setenas, las quales dichas penas mandamos que se repartan según dicho es, conforme a la ley del Fuero que la dicha villa tiene, de que ante Nos hizo presentación, la qual mandamos que vaya ynserta e yncorporada en la carta executoria desta nuestra sentencia.

[7] E otrosí, que devemos de mandar e mandamos que la dicha villa de Consuegra pueda ponery ponga un almotacén, el qual pueda cobrar e cobre las penas que los dichos alcaldes condegnaren en la dicha villa e su tierra, e que no la pueda cobrar ni cobre otra persona alguna, salvo el dicho almotacén que la dicha villa para ello pusiere.

[8] E otrosí, que devemos mandar e mandamos que los juezes e escrivanos e otros oficiales de el dicho prior de San Juan no puedan llevar ny lleven derechos algunos, salvo conforme al aranzel antiguo que la dicha villa de Consuegra e Horden tiene.

[9] Otrosí, que devemos de mandar e mandamos que el dicho prior ny sus oficiales no puedan dar ny den licencias para caçar en los términos de la dicha villa de Consuegra de presonas estrangeras de fuera de la dicha villa, pero bien permytimos que el dicho prior pueda caçar en los dichos términos si quysiere, no enbargante qualquier vedamiento que por la dicha villa de Consuegra sea sobre él puesta.

[10] E otrosí, que devemos de mandar e mandamos que el dicho prior ny su alcalde mayor no puedan enbiar presos fuera de la villa de Consuegra a los vezinos ni moradores de ella ny a otras qualesquier personas que en la dicha villa e sus términos cometieren delitos por que devan de ser presos, salvo si el tal delito fuere tan grande, grave e atroz que la cárcel pública de la dicha villa no fuese trota ny segura para guarda de los dichos presos o si los tales presos vinyesen presos ante el dicho prior o su alcalde mayor en grado de apelación.

[11] E otrosí, en quanto a lo de los mostrencos que por parte de la dicha villa de Consuegra fueren pedidos o demandados, que la dicha villa no provó su yntención y demanda en quanto a lo de los dichos mostrencos ny cosa alguna que le aproveche, e damos e pronunciamos su yntención por no provada e que la parte del dicho prior de San Juan provó sus esebciones e defensiones, e damos e pronunciamos su yntinción por bien provada. Por ende, que devemos de mandar e mandamos que el dicho prior lleve para sí de aquy adelante los dichos mostrencos, guardando en todo e por todo la ley destos Reynos que sobre los dichos mostrencos habla». 
No se condenó en las costas, pero se impuso una pena de I.ooo castellanos de oro al prior si no guardase lo contenido en la sentencia, que fue pronunciada en la audiencia granadina, el 28 de mayo de $1508 .{ }^{9}$

En la sentencia de revista la Chancillería confirmó la sentencia anterior, si bien con importantes «aditamentos y declaraciones»:

[1] «Que en quanto a lo de la caça, que devemos mandar e mandamos que el dicho prior de San Juan pueda dar licencia a los cavalleros que estovieren en su tierra e a sus criados por causa de su recreación e exercicio para que puedan caçar en los dichos términos.

[2] E otrosí, que pueda poner un alguazil e un tenyente que sean presonas conocidas e suficientes para usar e exercer el dicho oficio e para que executen sus mandamientos del dicho prior e su alcalde mayor e para que cobre sus rentas pechos e derechos a él pertenecientes.

[3] E en quanto a las penas, en lo que les toca a las penas de sangre que devemos de confirmar e confirmamos la sentencia por Nos en este dicho pleyto dada, la qual mandamos, en quanto a la dicha pena de la sangre, que sea llevada a pura e devyda execución con efeto en todo e por todo, según que en ella se contiene.

[4] E en quanto a las otras penas en la dicha nuestra sentencia contenydas, fallamos, atentos los abtos e méritos deste proceso e las provanças nuebamente hechas por parte del dicho prior e ante Nos traydas e presentadas, que la dicha nuestra sentencia, quanto a las dichas penas, que es de enmendar e para la enmendar que la devemos de revocar e revocamos en quanto a lo de las dichas penas, e, haziendo e librando en el dicho negocio lo que de derecho deve ser fecho, fallamos que la dicha villa de Consuegra, en quanto a lo de las dichas penas no provó su yntención e demanda ny cosa alguna que le aproveche e damos e pronunciamos su yntención, en cuanto a lo de las dichas penas por no provada e que el dicho prior de San Juan, en quanto a esto, provó sus esebciones e defensiones en todo aquello que provar devía e le convenía para se escluyr de lo contra él por parte de la dicha villa cerca de las dichas penas pedido e demandado, damos que pronunciamos su yntención por bien provada. Por ende, que devemos de absolver e absolvemos e damos por libre e quyto al dicho prior de San Juan de la demanda que sobre las dichas penas por parte de la dicha villa de Consuegra le fue puesta e ponemos perpetuo silencio a la dicha villa de Consuegra para que agora ny aquy ny aquí adelante ny en ningún tienpo pidan ni demanden al dicho prior de San Juan ny a sus çusesores cosa alguna sobre lo tocante a las dichas penas.

[5] E en quanto a lo mandado a los regidores de la dicha villa de Consuegra, fallamos que, en quanto a esto, atentas las nuebas provanças ante Nos traydas e presentadas, que la dicha sentencia es de enmendar para la enmendar en quanto a esto, que devemos de revocar e revocámosla, e, haziendo e librando lo que de derecho deve ser fecho, fallamos que devemos de mandar e mandamos que la dicha villa de Consuegra pueda poner los dichos regidores sin confirmación del dicho prior de San Juan no ecediendo el número antiguo».

\section{Tampoco en esta sentencia se impusieron costas (Granada, 31/03/1509).}

9. El prior apela. Son recibidos a prueba. El prior pide restitución, que le es concedida. El concejo se agravia y pide restitución. Se presentaron las probanzas y fueron publicadas. El concejo presenta escrito de bien probado. Dado traslado a la parte contraria, no contestaron, concluyendo y dando sentencia en grado de revista. 
En cumplimiento de lo dispuesto en el fallo, el escribiente que redactó la ejecutoria, con un evidente desconocimiento de la lengua latina, copió las cuatro leyes del Fuero que, pretendidamente, atañían a los temas juzgados. ${ }^{\text {Io }}$

Llegados a ese punto, el concejo consaburense solicitó que se le librase carta ejecutoria, siendo despachada de mano del escribano Juan Pérez de Barahona el 25 de mayo de I509. Iba rubricada por el obispo de Astorga, don Sancho Pérez Rodríguez de Acebes, y los oidores, Lcdos. Pedro González de Illescas, Cristóbal de Toro, Antonio de Segura y Rodrigo de la Corte, y el Dr. Ambrosio de Luna. Fue registrador el bachiller Salablanca. Consta que fue notificada tanto al prior como al Lcdo. Pedro de Avilés, su alcalde mayor, en sus personas.

Pasados algo más de 26 años, volvió a suscitarse el enfrentamiento entre el concejo de Consuegra y el mencionado alcalde mayor - ¿acaso llevaba siéndolo el mismo letrado, continua o espaciadamente?-; así, el 7 de diciembre de 1535 la villa presentó una querella contra el alcalde mayor, pues, estándole prohibido avocar las causas en primera instancia ni sacarlas del pueblo, y que prior ni alcalde mayor nombrasen alguacil mayor o teniente suyo, según ejecutoria anterior, y habiéndose dado muchas sobrecartas con grandes penas, el letrado había quebrantado los tres capítulos anteriores: «dezía que so color que hazía residencia y, lo que peor hera, que otras vezes, después que las avía remytido y se avía ydo, las tornava a advocar y nonbrava y ponía otro alcalde mayor en su lugar y a las vezes, dos, que se llamavan sus tenientes, y tanbién consentía y dexava que se pusiesen dos alguaziles mayores, y él los nonbrava a todos, contra el tenor y forma de las dichas cartas y sobrecartas. Solicitaba

10. «E las leyes del Fuero que por parte de la dicha villa de Consuegra fueron presentadas en este dicho pleyto son las siguientes:

[cap.1, 20] Quod palaciun no firmed super vicinun.

Palaciun no nunquan firmed super vicino.

Et yn codquunque calunyys palaciun ius abu[er]yd contiliun recibiad de una quaquaque calunia quartun et palaciun quartun et querelosus quartun et judex et alcaldes aliud quartun. Et quere primun querelosus abe[a]d quartun sun de calunia quy judex extorquere vel abere potueryt e de conposicione simyliter.

[cap. 9, 14] Que palaciun non acipiad homytudiun vysi domyny domy.

Palaciun vero non coligad homycidino nysi de morte domyny domynus solunmodo. Quecunque ecian yn domybus vel yn hereditatibus estererid seut vasalli domyny hereditatis e ybi respondead perpetua et faciendam.

[cap. 13, 6] Alcaldun non abead parten.

Preterea mando que neque palaciun nec alcaldes abead parten yn calunian desonestaciones neque ynpulsiones neque capiloriun neque yn calunia reperti nysi yn concilio aud in foro aut yn curia vel ad portas juditus factun fuerit. Predicti aut calupnire sibi patientis. Tamen quarta pars calunye debed exire alcaldes e reservare ad opus moruros et rerationem pecunye hujusmodi calunyarun.

[cap. 16, 1] De electione juditiis et alcaldun, notarii vel almytasaph et de jnstitucione aparitoriun e de mercedibus eorun.

Mando ecian que sequenti de dominica pos festun Santa Mycaelis contiliun ponat iudicin et alcaldes et notariun et questores, sayonen et admeltasaph anno per forun».

El Fuero de Consuegra no ha sido editado aún; el original se extravió del archivo municipal dos siglos atrás. Se conserva una copia en el Archivo Histórico Nacional, que planeo publicar próximamente. Sobre su contenido véase el trabajo de José Luis Bermejo, «Dos aproximaciones a los Fueros de Consuegra y de Soria», Anuario de Historia del Derecho Español, 2003, vol. LXXIII, pp. 101-136 (en lo que se refiere al fuero que nos ocupa).

La numeración de los capítulos y leyes la he tomado de la versión sistemática del Fuero de Cuenca (Rafael de UREÑA, El Fuero de Cuenca (Formas primitiva y sistemática: texto latino, texto castellano y adaptación del Fuero de lznatoraf), Madrid, 1936; hay reimpresión de la Universidad de Castilla-La Mancha, efectuada en Cuenca, 2003). He renunciado a corregir los numerosos errores del copista. 
que, porque sus partes gastavan mucho en se venir a quexar y llevar una sobrecarta y aquéllas avían sido muchas vezes», que mandasen ejecutar las penas contenidas en cartas y sobrecartas y que se enviase persona para que fuese notorio a los otros alcaldes mayores que viniesen en lo sucesivo y guardasen la ejecutoria, pagando todas las costas causadas. ${ }^{\text {II }}$

El concejo presentó una petición, en que pedía que el letrado fuese condenado por haber excedido y delinquido gravemente contra la ejecutoria, así por lo ya sabido como porque:

«Lo uno, porque el dicho prior de San Juan tenía puesto al dicho licenciado Avilés por su alcalde mayor y el que hera alcalde mayor no podía poner en su lugar a otros ny susdelegar, y en aquesto el dicho licenciado Avilés avía excedido notoriamente, porque se provava cómo avía puesto otros por sus tenientes e llamándolos alcaldes mayores, ansí en la dicha villa de Consuegra como en Alcáçar y en otros lugares, y porque para este efeto el dicho licenciado Avilés, siendo alcalde mayor, se nonbrava governador y usurpava este nonbre de tal manera que al que le nonbrava así le tomava odio y enemystad.

Y porque el dicho licenciado Avilés advocava ansí las causas e avía sacado muchos procesos e presos contra la dicha nuestra carta executoria, y para tener muchas vezes más color de hazer lo que quería, e que nunca los alcaldes hordinaryos conociesen de las causas, ya que se yva de la dicha villa, dexava un teniente, no lo pudiendo hazer.

Y porque, demás desto, so color de qualquier apelación de abto ynterlocutorio, diziendo que conocía en grado de apelación, advocava a sí las causas y nunca las remytía ny presos ny procesos.

Y porque lo que en esto avía esedido hera en gran manera, porque, como constava y parecía por el proceso, nunca otra cosa avía fecho ny hazía.

Y porque, no pudiendo aver más de un alguazil e un tenyente, conforma a la carta executoria, ponya muchos alguaziles, de que a sus partes y a todos los lugares de la dicha Horden les venía mucho daño e perjuyzio y hera usurpar lo que a otros pertenecía.

Y porque, estando en la villa de Alcáçar, que hera jurysdición distinta y apartada de la villa de Consuegra, dava mandamientos de execución e hazía otros abtos contra vezinos de Consuegra y sus alcaldes, y para aquello enbiava los thenyentes de alguazil que tenía puestos, no pudiendo eceder en lo uno y en lo otro.

Y sobre avérsele mandado que no lo hiziese, demás de la executoria, por abtos en vysta e revysta, que no diese los dichos mandamientos de hexecución, todavía lo hazía.

Y porque, so color que tomava residencia cada día que se le antojava, sacava los procesos y presos y los llevava a los otros lugares, no pudiéndolo hazer, ny menos tomar residencia, porque de esta manera, si ansí hovyese de pasar, serviría de poco efeto la carta executoria.

11. Se dio traslado a Juan de Medrano, procurador del Lcdo. Avilés, que presentó un escrito, en que aseguraba que había cumplido todos los requerimientos y testimonios pedidos por el concejo, que no avocaba las causas en primera instancia, que en todo caso entendía en las comisiones que se le daban o en la residencia que tomaba a los alcaldes y oficiales del concejo; que lo que ahora pedían era para dejar de rendir sus residencias. También con argumentos genéricos niega que incumpliese los otros dos puntos (sacar las causas fuera de la villa o poner alguaciles).

La parte del concejo concluyó y se dictó auto, mandando dar sobrecarta para que Avilés cumpliese la ejecutoria anterior. Respecto a los excesos que el concejo decía que el letrado había cometido, los reciben a prueba. Se realizan probanzas y se publican. 
Y porque de lo qu'estava provado resultava otros muchos agravyos y ecesos que el dicho licenciado Avilés avía fecho e hazía», pedía se le castigase por todo ello y se mandase a los futuros alcaldes mayores que cumpliesen lo que estaba ordenado.

En ese momento del procedimiento los concejos de Madridejos, Villafranca y Villacañas, persuadidos por el demandado, acudieron en su ayuda. ${ }^{\mathrm{I} 2}$ Dicha pretensión fue rechazada por el procurador de Consuegra. ${ }^{13}$ Finalmente, los oidores dictaron auto de vista (Granada, 08/05/1538) mandando al prior, a su alcalde mayor y a las justicias del priorato que viesen la ejecutoria librada años antes y la guardasen y cumpliesen y, haciéndolo,

[1] no nombrasen ejecutor para cobrar sus rentas, sino que lo hicieran los alguaciles de Consuegra.

[2] «Yten, en quanto al dicho prior e su alcalde mayor advocan a sí las causas que van ant'ellos en grado de apelación de abtos ynterlocutorios de los pleytos, ansí ceviles como crimynales, que ante los alcaldes de la villa están pendientes, mandaron al dicho prior de San Juan y a su alcalde mayor que quando el tal pleyto vinyere ant'ellos, reparen el agrayo que ant'ellos en grado de apelación vinyere y, reparado, lo tornen y remytan al juez o alcaldes que dello conocía, para que lo vea e sentencia difinytivamente, sin lo retener en sí.

[3] Otrosí, en quanto el dicho prior e su alcalde mayor nonbran alcalde mayor al tienpo que van fuera de la dicha villa, mandaron que no lo puedan hazer ny nonbrar, si no fuere saliendo de la juresdición de el dicho partido e priorazgo de San Juan.

[4] Otrosí, en quanto el dicho prior de San Joán y su alcalde mayor conocen de las causas saliendo de la dicha villa de Consuegra en las aldeas della, mandaron al dicho prior de [San Juan] e al dicho su alcalde mayor que vean la dicha carta executoria y la guarden y cunplan y executen como en ella se contiene y, en guardándola e cunpliéndola, no conozcan de las dichas causas, salvo en la dicha villa, según y como en la dicha carta executoria se contiene.

[5] Otrosí, en quanto al dicho prior e su alcalde mayor a conocido las causas e sacado procesos de la dicha villa e su juresdición por virtud de provysiones yncitativas, mandavan y mandaron

12. Comparecieron y alegaron que, «sobre dezir que el dicho alcalde mayor no podía conocer en los dichos lugares que heran de su jurysdición e terrytorio de la dicha villa de Consuegra de los pleytos que, estando en la dicha villa, a començado primeramente a conocer, salvo que, aunque estovyese en los dichos lugares, los avía de remetir ante los alcaldes della, y porque lo que el dicho concejo de Consuegra pedía hera en mucho daño e perjuyzio de los dichos concejos y vezinos de los dichos lugares, se opusieron al proceso, pidiendo que en relación con esto no se accediese a lo pedido por Consuegra, porque, aviendo començado a conocer el dicho governador primera en la dicha villa de Consuegra o en los dichos lugares de las dichas causas, aunque de la dicha villa saliese a los dichos lugares o algunos dellos, que heran todos de la jurysdición e terrytorio de la dicha villa de Consuegra y un cuerpo, ansí como podía conocer en la dicha villa pudía en los dichos lugares e no se dezía salir fuera, salvo quando estava en diversa jurisdición y aquello mesmo podían y hazían los alcaldes hordinaryos de la dicha villa, con los quales el dicho alcalde mayor avía lugar prevención de primera ystancia, ya quéello sienpre se avía entendido y platicado después y antes que la dicha carta executoria se diese, por donde se fundavan a hazer los pedimientos que pedían. Y porque lo susodicho hera mucha utilidad e provecho de los dichos pueblos y vezinos, porque comúnmente los governadores que se ponían heran letrados y de conciencia, que determinavan y guardavan justicia mucho mejor y sin menos costa y acesorías que llevavan los alcaldes de los dichos vezinos y no avía vejaciones ny molestias ny sacavan fuera de la juresdición, porque aquello avía sido prencipal causa de la dicha sentencia e carta executoria, y se abreviavan más los dichos pleytos».

Pedían que se entendiese así y presentaron las probanzas del Lcdo. Avilés, así como ciertos testimonios.

13. Así por lo ya pedido, como porque «las dichas aldeas no heran partes ny pretendían ynterese, antes venían contra lo que les conplía, y porque aquella oposición que hazía hera procurada por el dicho licenciado Avilés, haziéndoles a entender que les venía provecho, creyendo por esta vía escusarse de las penas en que avía yncurrydo por aver quebrantado la carta executoria, cartas e sobrecartas. Y porque la forma que estava dada no se podía alterar, aunque todos los pueblos juntamente consintiesen, quanto más las dichas aldeas, que no heran partes en aquesto. Y porque por esta oposición que la parte contraria avía procurado se vería claramente las formas y maneras que avía tenydo e tenía en este negocio». 
al dicho prior de San Juan e al dicho su alcalde mayor que no conozcan de las tales causas por virtud de las tales yncitativas, si no fueren en las causas que ante ellos estovieren pendientes, e no en otras algunas, salvo si no fuere por vía de comysión espresa del tal negocio.

[6] Otrosí, mandavan e mandaron al dicho prior de San Juan e al dicho su alcalde mayor que, durante el tienpo de su residencia que tomare, no saque nyngunas presonas ny procesos de los tales lugares donde se tomaren las tales residencias y allí las determinen y, so color de las tales residencias, no conozcan de otros pleytos ny causas algunas.

[7] E otrosí, en quanto el dicho prior e su alcalde mayor dan mandamientos de execuciones, mandavan e mandaron al dicho prior e su alcalde mayor que de aquy adelante no den los tales mandamientos de execución fuera de los lugares donde estovieren, salvo por requysitoria e no en otra manera.

[8] Y por quanto el dicho licenciado Pedro de Avilés no cunplió la dicha carta executoria, según e como devía, le condegnaron en las costas por parte de la dicha villa de Consuegra fechas, la tasación de las quales en sí reservaron».

Ante Juan Pérez de Barahona.

Aún se hicieron algunas alegaciones más por parte de prior y alcalde mayor, hasta que concluyeron, dictándose auto de revista (Granada, 30/Io/1538), por el que confirmaron el anterior, pero, en este caso, relevando a los apelantes de las costas de la instancia. ${ }^{\mathrm{I}}$

\subsection{PROCESO DE LOS CABALLEROS DE LA NÓMINA DE REQUENA CONTRA LOS REGIDORES PERPETUOS DE LA VILLA, QUE PRETENDÍAN ENTRAR EN LAS SUERTES ANUALES PARA SER CABALLEROS DE LA SIERRA (1549-1551) ${ }^{15}$}

Se había tratado pleito ante la Chancillería entre Pedro Ferrer, Martín Pedrón, Juan García Monzón y Pedro García Cuadra, caballeros de la nómina de la villa de Requena, de un lado, y, de otro, Gil Sánchez -o Sáez-Cutanda, Martín Zapata, Juan de Comas, Martín García, Miguel Sánchez, Cristóbal Hernández y Pedro

14. Notificado a las partes, el prior y el letrado suplicaron del auto de vista, exponiendo los motivos formales y negando los hechos. Si retenía autos interlocutorios apelados era porque así lo pedía la parte por haber recusado al juez de primera instancia. Además, insiste en que tenía derecho a hacer algunas de las cosas que le habían sido prohibidas.

Dado traslado a la parte de Consuegra, concluyó.

[aquí se omiten las cláusulas finales de la segunda ejecutoria original, de 11/11/1538].

El concejo de Consuegra, por cuanto se les había dado ejecutoria en papel y se les podía rasgar o perder, pide que se la den en pergamino.

Así lo acuerdan.

Se la dan en pergamino con sello de plomo colgando en hilos de seda de colores.

Doctores Peñaranda y Gálvez, oidores. Lcdo. Juan Sarmiento.

15. ARChG, expte. 5.754. Ejecutoria en siete pliegos. 
Pérez, regidores perpetuos de dicha villa, que se había iniciado ante el Dr. Ballesteros, corregidor de Requena, y llegó en apelación ante el presidente y oidores. En Requena, I4/09/1549, había comparecido ante dicho corregidor Diego Ruiz, procurador de Pedrón y consortes, y expuso

«que de tienpo ynmemorial acá y del tienpo que los que al presente heran vibos se acordaban y abían oydo desir a sus mayores e ancianos, ser usado e guardado que los caballeros de la nómyna de la dicha villa de Requena en cada un año, un domyngo después de San Myguel, segund lo mandava la ley del Fuero de la cibdad de Qüenca, al qual estaba poblada la dicha villa, ${ }^{16}$ en todas las tres perrochas hechaban entre sí suertes de los oficios siguyentes: alcaldes hordinarios e caballeros de Sierra, almotacén y alguazil, y aquel a quyen cabía por suerte uno de los dichos oficios no usaba d'él hasta que las personas del ayuntamiento de la dicha villa le daban poder para lo usar, y durante el año del dicho oficio no tenía ny usaba de otro.

Al presente el dicho juez hallaría que los regidores perpetuos de la dicha villa, tenyendo el oficios de regidores, pretendían entrar en las dichas suertes, lo qual hera contra la dicha costunbre ynmemorial y contra derecho y leyes y premáticas deste Reyno, las quales proyben tener dos oficios en concejo y fuera d'él, especialmente, siendo dibersos salarios e ynconportables, como lo heran los susodichos.

Por ende, que pedía al dicho juez que, abida su relación por verdadera en la parte que resultase para alcançar justicia, por su sentencia difinytiba que en tal caso lugar obiese, declarase los dichos regidores perpetuos que al presente heran e fuesen de aquy adelante para siempre, ora vezinos de la dicha villa, ora que fuesen a tener los dichos regimientos de fuera parte, no poder entrar ny dever ser admytidos a las dichas suertes $y$, sobre todo, pidió al dicho juez le hiziese entero cunplimiento de justicia, con protestación que azían que se quexarían a Nos».

\section{Dado traslado a la parte de los regidores, expusieron que desde 40 años atrás y de tiempo inmemorial ellos y sus regidores predecesores}

«los que heran de la nómyna de los caballeros [estaban] en costunbre pacífica de entrar en las dichas suertes y ser helegidos para caballeros de la Sierra, especialmente, porque hera oficio diberso y se conpadece que concurriesen con el del regidor, pues no hera de los oficios proybidos por derecho del Reino ny por las provisiones mías que thenían de los tales regimientos, por las quales solamente se proybía que tuviesen otros oficios de regimiento o juradería, y ansí de aquellos oficios que thenían votto en concejo y entravan en ayuntamiento o thienen cargo de la hazienda e propios del concejo, pero no se entendían ni hablavan en el oficio de cavalleros de Sierra, y por lo qual se conpadecía concurrir en una mesma persona él y el del regimiento.

E porque los regidores thenían por oficio de poder prendar e penar a los que entravan en los términos de la dicha villa y en los vedados della y a ellos más que a otros pertenescía guardar el término y conservar los montes, para lo qual principalmente avía sido ynvento e hallado el oficio dicho de cavalleros de Sierra.

E por ser ya absurdo dezir que por avernos fecho de los oficios de regimientos oviesen de perder el derecho e provecho que thenyan como tales cavalleros de la nómyna de poder entrar en las

16. Aunque sin duda existió, no se conserva el texto del Fuero extenso de Requena, tan sólo tres privilegios sucesivos de Alfonso X, concediéndoles el Fuero de Cuenca (1257) y el Fuero de las Leyes y los privilegios de los caballeros de Toledo y Cuenca (1264) y confirmándoles los fueros concedidos por Alfonso VIII y Fernando III (1268) (BARRERO, Ana María y Alonso Martín, Mari Luz. Textos de derecho local español en la Edad Media. Catálogo de fueros y costums municipales, Madrid, 1989, pp. 373-374). 
dichas suertes e de ser elegidos por cavalleros de Sierra, lo qual no dezían los dichos sus títulos, antes lo contrario en dezir que gozasen de todo aquello que los regidores antes gozavan en las dichas suertes de cavalleros de Sierra, seguíase que ellos avían podido e podían entrar y en ello no avía que altercar, porque solamente, como dicho hera, se les proybía thener otro oficio de regimiento e juradería y de alcaldía y otros como ellos, que thenían boto y no se conpadecían concurrir dos dellos en una mysma persona, pero el de cavalleros de Sierra, que se conpadecía y hera diverso a ello, no se entendía y así estava determinado en derecho que quando dos oficios que se conpadecen se consolidan en una mysma persona, que podían usar de entramos e gozar de los salarios e provechos a los dichos oficios ajenos [sic] y ellos dezían que protestavan gozar dellos, como hasta estonces se avía usado y de entrar en las dichas suertes, en especial, de cavalleros de Sierra, y de continuar e defender su antigua posesión en quanto a lo susodicho tocava.

Porque pedían e requerían al dicho juez, declarando los susodichos no ser partes para lo que pedían e no proseder su yntento, les absolviese e diese por libres y quytos de lo en contrario pedido, ynpunyéndoles cerca dello perpetuo silencio, e declarando poder e dever ellos [ser] admytidos al dicho oficio de la cavallería de Sierra, e los conservase y anparase en su posesión, condenándolos en las costas, las quales pedían e protestavan, y sobre todo pidieron al dicho juez les hizese entero cunplimiento de justicia».

Dado traslado a los demandantes, que alegaron, fueron recibidos a prueba, etc.

El Lcdo. Moro Dávalos, nuevo corregidor de Requena, dictó sentencia, en que expuso que los cuantiosos habían probado su intención, no así los regidores perpetuos, por tanto, que

«devo de declarar e declaro e mandar e mando que [de] oy en adelante los dichos regidores que son o fueren no entren ny sean admytidos en las suertes que suelen e acostunbran hechar en las tales yglesias desta villa entre las personas que tienen armas e caballo en los oficios de cavallería de Sierra y almotacenía y alcaldías [y] alguazilasgo, por quanto, conforme a derecho e leyes destos Reinos, los dichos regidores no pueden tener dos oficios que no se conpadecen en una persona ny menos conforme al Fuero municipal de la cibdad de Qüenca, a que esta villa está poblada, donde los regidores della no entran en las dichas suertes.

Y porque por este proceso paresce estar los dichos regidores en posesión bel casi de entrar en las dichas suertes los añales y perpetuos y abérseles cabido suertes de caballeros de Sierra, y al presente le cupo a Miguel Sánchez regidor y fue admitido en las dichas suertes, que acerca deste artículo e juizio posesorio en el ynterin no ynobo cosa alguna.

Y porque ay peligro en la tardança, mando que mañana domyngo, a la hora que suelen e acostunbran echar las dichas suertes, se hechen conforme como lo an de huso y costunbre, y en caso que cupiere algunos de los dichos regidores alguna suerte de caballería e almotacenía e alcaldía [o] alguazilazgo, mando que los dichos regidores luego yn continente como les cupiere la suerte den fianças legas, llanas e avonadas de bolber e restituyr los yntereses e aprobechamientos e borras de caballeros de la nómyna desta villa durante el tienpo que ansí tubieren los dichos oficios, si esta mi sentencia fuere confirmada en propiedad e posesión por los señores superiores que de la causa puedan e devan conozcer. Sin costas» (Requena, 12/10/1549).

Fue apelada por ambas partes, si bien quien se presentó en Granada fue Pedro García Cuadra, al que se dio carta de emplazamiento y compulsoria contra los regidores. Se trajo el proceso y Antón Hernández, procurador de aquéllos, pidió se confirmase en lo favorable, pero que 
«avía hecho notorio agrabio a sus partes, porque la avía probeydo sin pedimiento de parte, pues, no estando pedido por las partes contrarios que las anparasen en el entretanto, no la había podido hazer, y porque, aunque estubiera pedido, pues le abía costado por el proceso que nunca los regidores de la dicha villa avían entrado en suertes de los oficios sobre que se litigaba, y, si alguna vez avían entrado, avía sido por fuerça e por fabores que avían thenido, de tal manera que no avían ganado posesión, no avía devido de anparalles en ella, antes deviera de mandar guardar las que sus partes avían thenido siempre, e porque, aunque le constara claramente que la parte contraria avía estado en posesión, por ser como hera posesión a que resistía el derecho, no avían de ser anparados en ella si no fuese mostrando título a lo menos colorado»,

por lo que pedía que se anulase en este punto.

\section{Dado traslado a la parte contraria, no contestó cosa alguna.}

La parte de los regidores, entre tanto, se había presentado ante el Consejo Real en apelación, que les fue rechazada, siendo remitidos de nuevo ante la Chancillería.

Presentado ante la misma Francisco de Santisteban, procurador de los regidores, presentó un escrito de agravios, pidiendo se revocase la sentencia del corregidor en todo lo que era contrario a sus intereses, pues había costumbre antigua de que ellos entrasen en las suertes de esos oficios, así como «el previllegio que la dicha villa thenya usado e guardado»; que siendo regidores perpetuos por provisión real no eran de menor condición para ser caballeros de la nómina:

«no heran de menor condición para que, siendo cavalleros de nómina, como heran, e theniendo armas y cavallo, como thenían, no fuesen admytidos a las suertes de los oficios, porque por ser regidores por nuestro mandado se avía acrescentado onra de los dichos oficios y no se avía mudado la condición e las premynencias que los regidores añales thenyan en tiempo que los avía, antes se avía acrescentado para su conservación, lo qual no avía de obrar diminución, como las partes contrarias querían, porque constava e parescía y estava muy enteramente provado que los regidores añales que heran de cavalleros de nómina de tiempo ynmemorial, aunque fuesen regidores, entravan en las dichas suertes y heran nonbrados a los dichos oficios y los usavan y exercitavan como tales cavalleros de nómina, conforme a la costunbre antigua que en la dicha villa se a thenido e thenya, e no se avía podido fundar por dezir que no usavan dellos hasta que se nonbravan otros regidores, porque la fuerça no estava, salvo en el nonbramiento, aunque fuesen regidores, e por esos sus partes avían de ser dados por libres, pues, aunque heran regidores, entravan en las dichas suertes, e si no usavan hera porque luego heran elegidos otros regidores, conforme a la costumbre, y no otra cosa alguna.

E porque, bien myrada la provisión y merced que se avía dado a sus partes, por ella solamente se mandava que no tuviesen otros oficios de jurados e regidores de cabildo ny fuesen de primera corona, y lo susodicho sus partes no lo thenyan ny tal estava provado ny hera oficio de concejo para que no se pudiese atolerar y no fuese aconpatible, y así mostrava claramente que sus partes, aunque fuesen cavalleros contiosos, podían thener los dichos oficios y que justamente estavan en la posesyón, e que las leyes del Reino no lo proybían, pues heran oficios conpatibles, especialmente, viendo cómo avía echo regidores por nuestro mandado y que antes heran dos, donde avía los ynconvinyentes que las partes contrarias dezían, lo qual cesava en su casso, y, así, después que avían sido rescibidos por nuestro mandado, siempre avían entrado en las dichas suertes y avían gozado de los dichos oficios y avían thenido parte de borras y cavallerías de Sierra, sin aver perjuizio alguno, y no aver ley que lo susodicho proybiese y mandase que no lo thenyan.

E pues las partes contrarias pedían a sus partes que no fuesen admytidos, justamente el juez los avía mandado anparar en su posesión entre tanto que el dicho pleito se determinava, pues, aunque no lo declarasen, sus partes avían estado y estavan en la dicha posesión por la dicha costunbre e previllegios e mercedes». 
Así mismo, pidió que su parte fuera recibida a prueba, a pesar de estar el proceso concluso, durante su rebeldía, cuando fueron a apelar ante el Consejo.

Dado traslado a los caballeros, contestaron que cuando los regidores eran anuales nunca habían entrado en las suertes de los oficios, sino sólo cuando habían dejado sus regimientos y se habían provisto nuevos regidores,

«pero nunca jamás avían usado de dos oficios juntos e como al presente los regimientos heran
perpetuos, no avían de ser de mejor condición ny de más prehemynencia que de antes, pues en
la mysma merced que thenya de los oficios se expresava de lo contrario, e porque demás de ser
lo susodicho ansí y estar declarado por costumbre de derecho, hera lo mysmo, pues por Derecho
Comund, nynguno podía thener dos oficios yncompatibles, como sería ser regidor y almotacén e
cavallero de Sierra e alcalde hordinario o de Hermandad, pues no podía servir del uno e del otro
juntamente e de derecho del Reino se proybía expresamente a los regidores que no pudiesen
thener dos oficios en el concejo, e porque los que heran cavalleros de Sierra o almotacenes then-
yan los oficios con poder de los regidores e oficiales del concejo, de manera que lo suso dicho
fuera cosa yncompatible que como regidor de poder, así mysmo para ser cavallero de Sierra.
E porque de lo susodicho se colegía que thodos los frutos e yntereses que las partes con-
trarias avían llevado por razón de los dichos oficios, que con las borras y tajas e pren-
das e otros aprovechamyentos y derechos heran obligados de restituyllos a sus partes». Así pedía que se condenara a la parte contraria.

Dado traslado a los regidores, se concluyó y se les recibió a prueba, se presentaron las probanzas y se hizo publicación de las mismas, presentándose escrito de bien probado y dictándose sentencia:

«Fallamos que el licenciado Moro Dávalos, corregidor de la dicha villa de Requena, que d'este proceso conozció, que en la sentencia difinityba que en él dio e pronunció, de que por amas las dichas partes fue apelado, que en quanto por ella declaró y mandó que los dichos Gil Sáez Cutanda y sus consortes, regidores de la dicha villa, no pudiesen entrar en suertes con los dichos Pero García Quadra y sus consortes en los oficios de caballeros de Sierra y almotaçanía y alguazilazgo de la dicha villa, juzgó e pronunció bien, y los susodichos apelaron mal.

Por ende, que en quanto a lo susodicho debemos confirmar y confirmamos su juizio e sentencia del dicho juez, la qual mandamos que se guarde, cumpla y execute como en ella se contiene.

Y en todo lo demás en la dicha sentencia contenido el dicho juez juzgó e pronunció mal y los susodichos apelaron bien.

Por ende, que debemos rebocar y rebocamos su juizio e sentencia del dicho juez y la damos por ninguna e de ningún efeto e valor». Sin costas.

Suscribieron el fallo el obispo de Ávila y los licenciados Huarte y Arana (Granada, Io/o9/1550).

Los regidores perpetuos apelaron, sin que se llegasen a presentar nuevas probanzas. Luego, dictaron sentencia de revista, en la que confirmaron en todos sus términos la de vista, condenando a los apelantes en las costas por haber suplicado 
mal. En este caso, la rubricaron el obispo de Ávila y los licenciados Salas, Arana y Huarte (Granada, 24/OI/I55I). ${ }^{17}$

\section{CONCLUSIONES}

Como se ha podido apreciar, los problemas que preocupaban a los hombres del siglo XVI estaban muy relacionados con las preeminencias concejiles y personales, lo que no es extraño en una época en que empezó a romperse de forma estrepitosa la unidad de fuero de los habitantes de las villas pobladas a Fuero de Cuenca con la ascensión de los hidalgos. ${ }^{18}$ Ambas ejecutorias tienen en común ocuparse de las elecciones de los aportillados u oficiales de concejo.

Por lo que se refiere a las pretensiones contenidas en la ejecutoria ganada por el concejo de la villa de Consuegra, destacan dos puntos relacionados directamente con los contenidos de su fuero: la elección de los oficios municipales y el reparto de las caloñas por los diferentes delitos. En cuanto a las elecciones, sostenía el concejo que tenían costumbre de celebrarlas el domingo posterior al día de San Miguel, designando alcaldes ordinarios, regidores y alguacil, entre personas ricas y abonadas, hábiles y suficientes para ello; la elección la llevaban a cabo los oficiales salientes, debiendo ser confirmados los entrantes por el prior de la Orden. En la sentencia de vista del proceso de I509 se hizo una declaración, detallando el modo de la elección, pero preservando el derecho prioral a confirmar a los electos, sin embargo, en el fallo de revista se suprimió esa preeminencia.

El segundo punto relacionado directamente con el fuero era la percepción de las penas; el concejo afirmaba que normalmente al prior no le correspondía llevar nada - pues solían destinarse al mantenimiento de las murallas-, salvo la cuarta parte de algunas. Estableció la sentencia de vista que el prior había de cobrar la cuarta parte de los homicidios, del forzamiento de mujer o de la fuerza causada en casa de señor, así como las setenas de los hurtos. En el fallo de revista, por el contrario, se dispuso la revocación en este caso de la sentencia anterior, atribuyendo al prior la percepción de todas las penas, salvo las provenientes de delitos de sangre.

17. Los caballeros solicitan se les libre carta ejecutoria. Se tasan las costas en $1.530 \mathrm{mrs}$. Acuerdan librar la ejecutoria, ordenando las justicias cumplir las tres sentencias contenidas y que en tres días abonasen los 1.500 mrs. a la parte a los caballeros cuantiosos. [Obispo de Ávila]. Lcdos. Huarte, Salas y Arana.

Tal vez relacionada con este proceso, a fines de agosto de 1551 se libró una sobrecarta de una compulsoria con mayores penas, con dos ducados de costas y 210 mrs. de derechos de la provisión, contra el escribano real Martín Morquecho, a petición del concejo de Requena y del cabildo de los caballeros de la nómina. En la primera compulsoria (de fines de diciembre del año anterior) se había ordenado a Francisco de Barrionuevo, juez de comisión, «que, si avía procedido de su oficio en ciertos procesos que contra los susodichos avía fecho sobre el registro de los cavallos, enbiase la causa y razón, e si a pedimiento de parte la nombrase y emplazamyento contra quien nonbrase y compulsoria para el escrivano ante quién avían pasado los dichos procesos, le diese un traslado dellos en manera que fiziese fee» [sic]. El escribano se había mostrado negligente en dar el traslado (ARChG, expte. 5.760).

18. Ha llamado mi atención sobre este punto el profesor Díaz de la Guardia, de la Universidad de Granada, experto en el campo de las hidalguías y mitades de oficios. 
Respecto a las caloñas, disponía el Fuero -de acuerdo con los artículos transcritos por el escribiente de forma macarrónica en el proceso- en su ley i/20, forma sistemática, que se repartieran por cuartos entre el palacio -o sea, el señor, en este caso, el prior-, el querelloso, el juez y los alcaldes. Quiere decirse que esta norma quedaba abolida por la anterior sentencia.

Por su parte, la ley 9/I4 disponía que el señor sólo cobrase la caloña correspondiente al homicidio del dueño de la casa.

La ley I3/6 también trataba sobre el reparto de las caloñas: dispone que ni señor ni alcaldes perciban las penas pecuniarias por denuestos, empujones, toma de cabellos o reto, salvo que se cometiesen estos delitos en el concejo abierto, en el mercado, en la sala de justicia de los alcaldes o ante las puertas del juez. El resto de las caloñas serían para la víctima -el querelloso-, pero la cuarta parte debería entregarse a los alcaldes para que la destinasen al arreglo de las murallas.

Por otro lado, la ley i6/I establecía que el domingo siguiente a la festividad de San Miguel el concejo eligiese juez, alcaldes, escribano, andadores, sayón y almotacén, con mandato para un año; en la ley posterior, no recogida por el escribiente, se reitera dicha anualidad, añadiendo que la collación en que ese año cayera el juzgado -el derecho a elegir juez-designase una persona prudente, circunspecta, capaz de distinguir lo verdadero de lo falso y lo justo y lo injusto; el nuevo juez debería tener casa poblada en la villa y caballo apropiado desde un año antes. En la ley siguiente se extiende esa misma obligatoriedad de poseer casa y caballo para los alcaldes elegidos en las collaciones.

Así pues, tanto en el caso de las caloñas como en el de las elecciones, las viejas soluciones son alteradas según las nuevas circunstancias, de acuerdo con los cambios institucionales habidos.

Por lo demás, el resto de las quejas iban dirigidas más a las actuaciones del alcalde mayor del priorato que al prior, propiamente dicho. Se trata de cuestiones que por aquellos años eran temas candentes también en las cercanas tierras de la Orden de Santiago y que, en muchos casos, venían de lejos. Se trataba de fijar las reglas del juego entre las preeminencias de los señores y los derechos de los vasallos, en un tira y afloja en que aquéllos jugaban a los hechos consumados, obligando a sus encomendados a acudir continuamente ante la justicia real para intentar recomponer el statu quo previo, algo que conseguían sólo parcialmente, como lo muestra la carta ejecutoria de los consaburenses. ${ }^{19}$

Se quejaban los de Consuegra de que el alcalde mayor avocaba continuamente las causas que les correspondía librar a los alcaldes ordinarios, sacando procesos y presos fuera del pueblo cuando salía del mismo. Aunque en este punto se podía

19. Se conserva en el archivo de la Chancillería granadina otra voluminosa ejecutoria, de mediados del siglo XVI, de un proceso entre el concejo y el marqués de Comares (Axarquía de Málaga) por los agravios que los vecinos recibían de éste; en este caso no se esgrimía la violación del fuero, lógicamente, sino las condiciones de asentamiento de sus nuevos pobladores, dispuestas por los Reyes Católicos. 
alegar la práctica procesal de tiempos del fuero, cuando era propia de los alcaldes la jurisdicción en primera instancia, lo cierto es que, como había ocurrido con los oficiales del concejo - en el tiempo del fuero, sólo juez y alcaldes, con una larga serie de aportillados menores; ahora, alcaldes ordinarios, regidores, alguacil, almotacén, caballeros de la Sierra, etc.-, la situación había evolucionado mucho, sobre todo a partir del siglo XIV y aquella realidad era difícilmente reconocible en el siglo XVI.

En este punto, la sentencia de vista ordenó que se respetase la jurisdicción en primera instancia de los alcaldes ordinarios, salvo que el alcalde mayor se encontrase en la villa; en ese caso, conocería éste, pero dejaría las causas en manos de los ordinarios cuando abandonase el pueblo. Ya en el proceso de I535 se verán los subterfugios usados por el alcalde mayor para evitar cumplir lo así ordenado, pues seguía avocando sin pudor alguno, además, tomaba residencia a su antojo a alcaldes y demás oficiales, actuaba desde Alcázar de San Juan -su probable lugar fijo de residencia-, continuaba el conocimiento de los procesos de los que una parte se agraviaba de sentencia interlocutoria y seguía sacando del término de Consuegra a los litigantes locales. Así mismo, se llamaba a sí mismo «gobernador» y nombraba tenientes suyos, permaneciendo dentro de los límites del priorato.

En lo que se refiere al extraer litigantes de su domicilio, se dispuso en la sentencia de vista que no se hiciese, salvo que el delito fuese atroz y la cárcel local no ofreciese condiciones de seguridad para evitar la huida del reo.

Se acusaba, así mismo, a la justicia del partido de que ponía alguaciles/receptores propios para cobrar derechos y de que no respetaban el arancel existente, percibiendo derechos excesivos. En la primera sentencia se le ordenó respetar dicho arancel, pero, en cuanto al nombramiento de ejecutor, se plantearon dudas a los oidores, que decidieron pensárselo. Ya en la de vista permitieron que el prior nombrase un alguacil y su teniente para sus asuntos propios, manteniendo las competencias del alguacil municipal. Pasados más de cinco lustros, el alcalde mayor seguía interfiriendo en esas competencias del alguacil local, nombrando propios en concurrencia con éste.

El resto de las cuestiones versan sobre problemas rutinarios entre señores y vasallos: el prior les exigía servicio de transporte con sus carretas, sin pagarles lo debido; les prohibía cazar en sus propios términos; llevaba los bienes mostrencos y pretendía que todos usasen el molino de la Orden para moler su pan. ${ }^{20}$ Los oidores no se pronunciaron en estas sentencias sobre el primero y el último de estos cuatro puntos, no así de los otros dos. Con claridad desestimaron la pretensión del concejo de percibir los bienes mostrencos - generalmente, ganado hallado extraviado, sin dueño conocido- $y$, en lo referente a la caza, primeramente, se

20. Sobre este asunto véase mi trabajo Los molinos de viento de la Mancha santiaguista. El molino como síntoma y como símbolo, Campo de Criptana, 2016. 
respetó el derecho a reglamentar la caza al municipio, pero permitiendo que el prior cazase a su antojo, donde y cuando le pareciese, pero luego, en revista, se amplió esa licencia al prior para que caballeros y criados suyos pudieran cazar, a despecho del concejo.

Menos enjundia tiene la carta ejecutoria ganada por los caballeros de cuantía de Requena; el conflicto se planteó entre los miembros de la oligarquía local: por un lado, los regidores perpetuos, que habían comprado sus cargos a la corona, y, por otro, los caballeros cuantiosos, aspirantes a convertirse en hidalgos, que deseaban seguir monopolizando el desempeño de los oficios municipales, en particular, las caballerías de la Sierra, que permitían a los que las ocupaban prendar y penar a los infractores por los daños causados en los montes y/o dejarse cohechar por éstos para que les permitieran causar esos daños. ${ }^{2 \mathrm{I}}$ Se trataba, pues, de un oficio muy lucrativo.

Al tiempo del fuero no existían aún caballeros de cuantía, pero sí caballeros pardos, puesto en el que aquéllos se subrogaron, y era a estos vecinos que mantenían caballo y armas a quienes se atribuían los oficios de juez o alcalde; más tarde, cuando se estableció el consejo de regidores y se abolió, consecuentemente, el régimen del concejo abierto, alcaldes, regidores, alguacil y demás oficios de importancia se seguían reservando a estos cuantiosos. Por tanto, la pretensión de los regidores perpetuos de acceder de modo ordinario a las caballerías de la Sierra no podía ser mantenida en derecho, máxime dándose duplicidad de cargos, como el concejo se encargó de mostrar con éxito, amparándose para ello tanto en la legislación nacional como en el derecho común.

En realidad, la cuestión que más alarmó a los caballeros de la nómina no fue tanto el derecho de los regidores perpetuos a entrar en las suertes para caballeros de la Sierra, algo que les era fácil de impugnar, como la posesión del mismo que el corregidor les había reconocido ad cautelam, en primera instancia. Afortunadamente para los caballeros, la Chancillería confirmó dicho derecho y rechazó la posesión de los regidores. Se especifica en la ejecutoria, por otro lado, que los oficios eran elegidos en las tres parroquias de que disponía la villa.

Así pues, eran varios los puntos en los que el Fuero de Cuenca seguía vivo, siquiera fuera de una forma muy parcial, referidos tanto a las elecciones de oficios municipales y la percepción de los derechos y preeminencias a ellos inherentes como a la cobranza de algunos derechos por el municipio, como es el caso de las distintas caloñas que hemos visto en Consuegra, si bien, los cambios habidos en el ámbito administrativo, penal y procesal-penal, convertían las antiguas normas en agua de borrajas. Realmente, da la impresión de que conforme avanzaba el

21. Es una constante en los juicios de residencia del siglo XVI que he leído la acusación de que los caballeros de la Sierra de los distintos concejos se dejaban cohechar continuamente, eso si no eran ellos mismos los que causaban daños, durante su desempeño como vigilantes forestales. 
siglo XVI las invocaciones al Fuero de Cuenca cogían con pinzas sus contenidos, difícilmente adaptables a las condiciones del momento.

\section{FUENTES Y BIBLIOGRAFÍA}

Barrero, Ana María y Alonso Martín, Mari Luz: Textos de derecho local español en la Edad Media. Catálogo de fueros y costums municipales, Madrid, 1989.

Bermejo CABrero, José Luis: «Dos aproximaciones a los Fueros de Consuegra y de Soria», Anuario de Historia del Derecho Español, 2003, vol. LXXIII, pp. IoI-I63.

Llano, Lcdo. Pedro Nolasco de: Compendio de los comentarios extendidos por el maestro Antonio Gómez a las ochenta y tres Leyes de Toro ..., Madrid, I785; reimpresión en Lex Nova, Valladolid, I98I.

Peset, Mariano, Gutiérrez Cuadrado, Juan y Trenchs Odena, Josep: Fuero de Úbeda, Valencia, I979.

Porras Arboledas, Pedro Andrés: «Fuero de Sabiote», Cuadernos de Historia del Derecho, I994, vol. I, pp. 243-44I.

Porras Arboledas, Pedro Andrés: «Los Fueros de Alcalá de Henares. Introducción históricojurídica», Homenaje al profesor Alfonso García-Gallo, Madrid, I996, vol. III, pp. I3I-I88.

Porras Arboledas, Pedro Andrés: «Un protocolo ubetense de I459 y otros documentos procesales de los siglos XV y XVI», Cuadernos de Historia del Derecho, 2006, vol. XIII, pp. 3II-345.

Porras Arboledas, Pedro Andrés: «Sobre el Fuero extenso de Mérida», Cuadernos de Historia del Derecho, 2012, vol. XIX, pp. 27-48.

PORRAS ARbOLEDAS, Pedro Andrés: «Sobre el Fuero extenso de Segura de la Sierra (El poblamiento de la villa de Santiago de la Espada)», Revista de la CECEL, 20I4, vol, XIV, pp. 7-22.

Porras Arboledas, Pedro Andrés: Los molinos de viento de la Mancha santiaguista. El molino como síntoma y como símbolo, Campo de Criptana, 2016.

Porras Arboledas, Pedro Andrés, Herranz Torres, Alberto y Escudero Buendía, Francisco Javier: Documentos medievales del Archivo Municipal de Alcázar de San Juan (siglos XII-XV), Alcázar de San Juan, 2012.

UreÑA, Rafael de: El Fuero de Cuenca (Formas primitiva y sistemática: texto latino, texto castellano y adaptación del Fuero de Iznatoraf), Madrid, I936; reimpresión de la Universidad de Castilla-La Mancha, efectuada en Cuenca, 2003. 
Calidad de Revistas

científicas Españolas

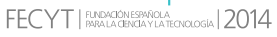

SERIE III HISTORIA MEDIEVAL

REVISTA DE LA FACULTAD DE GEOGRAFÍA E HISTORIA
AÑO 2018

ISSN: 0214-9745

E-ISSN 2340-1362

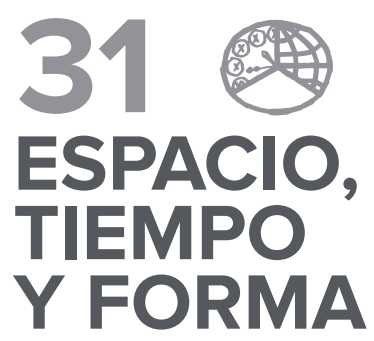

GREGoRIO DEL SER QUIJANO

Carmelo Luis López, In Memoriam

\section{Artículos · Articles}

29 Soha ABBoud Haggar

Un resumen del tratado jurídico de Al-Tafrí: el Manuscrito Árabe 1233 del Monasterio de El Escorial y su supuesta relación con Leyes de Moros

EDUARDo Aznar VALLejo

Norma y conflicto en la navegación castellana bajomedieval

69 Carlos Barquero Goñ

Transferencias de recursos de la Orden de San Juan desde España hasta el Mediterráneo Oriental durante la Edad Media

\section{Margarita Cabrera Sánchez}

La muerte del príncipe Don Juan. Exequias y duelo en Córdoba y Sevilla durante el otoño de 1497

\section{Francisco de Paula Cañas Gálvez}

Primogenitura, continuidad dinástica y legitimitad instituciona en Castilla a principios del siglo XV: Catalina de Trastámara, Princesa de Asturias (1422-†1424)

\section{Paloma Cuenca Muñoz}

El códice visigótico de los Moralia in lob, ms. lat. 83 de la John Rylands Library de Manchester

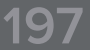

\section{JOSÉ MARÍA DIAGO JIMÉNEZ}

Las instituciones educativas de carácter religioso en el reino hispanovisigodo de los siglos VI y VII a través de los cánones conciliares y las reglas monásticas

MARÍA Díez Yáñez

La Ética aristotélica en Castilla: las bibliotecas universitarias medievales y prerrenacentistas

\section{Estefanía Ferrer del Río}

Rodrigo de Mendoza, I Marqués del Cenete y I Conde del Cid: paralelismos entre su biografía y su pretendida genealogía

\section{ALEJANDRo García Morilla \\ Escritura publicitaria de transición: entre la visigótica y la carolina.} El paradigma burgalés

María Dolores García Oliva

Señores contra campesinos: un conflicto por la tierra en Mirabel a finales de la Edad Media y principios de los Tiempos Modernos (1488-c. 1520)
34.3 jaime García Carpintero lópez de Mota

La hospitalidad santiaguista a finales de la Edad Media: el proyecto de reconstrucción del hospital de Alarcón

377 LAURA DA GRACIA

La posesión agraria individual en los registros notariales de Fuente el Sol (1481-1482

4.03 Mauricio Herrero Jiménez

El valor de los documentos reales en los procesos de la Real Chancillería de Valladolid

431 Miguel José López-Guadalupe Pallarés

Procesos de señorialización en los concejos de la Extremadura castellano-leonesa. Un estado de la cuestión

455 Ángel Martínez Catalán

Las rentas decimales del cabildo catedralicio de Cuenca a inicios del siglo XV (1400-1432)

4.83 Gonzalo Oliva Manso

Cien años de moneda en Castilla (1172-1268). El siglo del maravedí de oro

521 jesús Olivet García-Dorado

El cabildo de curas y beneficiados de Toledo en la segunda mitad del siglo XV. Composición y aspectos institucionales (1455-1488)

547 Mariel PÉrez

Clérigos rurales, comunidades y formación de las estructuras parroquiales en la diócesis de León (siglos XI-XIII)

575 Milagros Plaza Pedroche

La Orden de Calatrava en la Baja Edad Media (1350-1500): repaso historiográfico

597 Pedro Andrés Porras Arboledas

La pervivencia del Fuero de Cuenca en los inicios de la Modernidad: el testimonio de los fueros de Consuegra y Requena

619 Juan Pablo Rubio Sadia

Los mozárabes frente al rito romano: balance historiográfico de una relación polémica

SANDRA SUÁREZ GARCíA

Los habices de la Vega de Granada como forma de conocimiento del reino nazarí y su transformación tras la conquista: la alquería de La Zubia 


\section{1}

\section{ESPACIO,}

\section{TIEMPO}

\section{Y FORMA}

SERIE III HISTORIA MEDIEVAL

REVISTA DE LA FACULTAD DE GEOGRAFÍA E HISTORIA

\section{De medievalistas ilustres · On Renowned Medievalists}

671 Francisco Abad Nebot

Entradas para un Diccionario

\section{Libros $\cdot$ Books}

679 Almagro Vidal, Clara, Paisajes medievales en el Campo de Calatrava (CARLos BARQUero GoÑI)

681 Carvajal Castro, Álvaro, Bajo la máscara del Regnum. La monarquía asturleonesa en León (854-1037) (JOSÉ MANUEL RODRÍGUEZ GARCíA)

683 Fuente Pérez, María Jesús, Violante de Aragón, reina de Castilla (ANA ECHEVARRía ARsuaga)

687 Martín Prieto, Pablo, Historia del pensamiento medieval: filosofia y teología (FRANCISCO LEÓN FLORIDO)

689 Pardo de Guevara y Valdés, Eduardo (ed.), Mujeres con poder en la Galiciamedieval (siglos XIII-XV). Estudios, biografías y documentos (ENRIQUe CANTERA MONTENEGRO)

693 Ríos Saloma, Martín (ed.), El mundo de los conquistadores (Jessica Ramírez MéndeZ)

690 Solórzano Telechea, Jesús, Arízaga Bolumburu, Beatriz y BOCHACA, Michel (eds.), Las sociedades portuarias de la Europa atlántica en la Edad Media (ANTONIO ORTEGA VILLOSLADA)

703 VAL VALDIVIEso, María Isabel del (coord.), El agua en el
imaginario medieval. Los reinos ibéricos en la Baja Edad Media (MARÍA Jesús Fuente)

707 Villar García, Luis Miguel, Archivo Municipal de Segovia. Documentación medieval, 1166-1474 (ENRIQUE CANTERA MONTENEGRO) 